University of Nebraska - Lincoln DigitalCommons@University of Nebraska - Lincoln

Anthropology Faculty Publications

Anthropology, Department of

Summer 8-1-2017

FEMINIST SCIENCE AND CHACOAN ARCHAEOLOGY: REPLY TO WARE.

Carrie Heitman

University of Nebraska-Lincoln, cheitman2@unl.edu

Follow this and additional works at: http://digitalcommons.unl.edu/anthropologyfacpub

Part of the Archaeological Anthropology Commons, and the Social and Cultural Anthropology Commons

Heitman, Carrie, "FEMINIST SCIENCE AND CHACOAN ARCHAEOLOGY: REPLY TO WARE." (2017). Anthropology Faculty Publications. 149.

http://digitalcommons.unl.edu/anthropologyfacpub/149

This Article is brought to you for free and open access by the Anthropology, Department of at DigitalCommons@University of Nebraska - Lincoln. It has been accepted for inclusion in Anthropology Faculty Publications by an authorized administrator of DigitalCommons@University of Nebraska Lincoln. 


\title{
FEMINIST SCIENCE AND CHACOAN ARCHAEOLOGY: REPLY TO WARE
}

\author{
Carrie C. Heitman
}

Ware's comment misses the point of Heitman's (2016) article and further demonstrates the need for feminist science perspectives.

El comentario de Ware no comprende lo fundamental del artículo de Heitman (2016) y demuestra aún más la necesidad de perspectivas científicas feministas.

$\mathrm{W}$

are launches three critiques in his comment, not all of which are based on my American Antiquity article.

While constructive criticism can help to clarify arguments and viewpoints, I fear that a more productive discussion of the points on which Ware and I agree and even disagree gets lost in the truculent tone of his comment. In the brief space allowed, I will address each in turn with the hope of moving the conversation productively forward.

I thank Ware for shining additional light on the need for ontological and equity critiques to advance feminist science and for providing an opportunity to expand upon my earlier publication. Let me clarify what my 2016 article was and was not about. It aimed to amend certain omissions, erasures, and androcentrisms in the broad body of literature on Chacoan archaeology. My article was about neither house society models nor descent theory. It was about the ethnographic and legacy archaeological data that make women more visible than they had been in previous conceptions of Chacoan society, data that, when brought to light, demonstrate gender complementarity.

Matrilineality is an important aspect of many Puebloan societies; on that point, Ware and I agree. My article, however, focused on other aspects of gender in the ethnographic and archaeological record. I deferred presenting an in-depth discussion of the importance of Puebloan matrilineality, so I appreciate Ware highlighting it in his comment. However, I contend that "grounding" his avunculate hypothesis in matrilineality does not negate my critique of his 2014 work as androcentric. Indeed, his use of the phrase "grounded in matrilineal theory" is illuminating, because the core avunculate thesis of Ware's book is centered on men. For Ware, avunculate sodalities are the "figure" and matrilineality is the "ground" they appear against. Similarly, Ware juxtaposes male "authority" to female "symbolism" in his comment with the implication that women had no authority. In contrast, my article explicitly highlighted male and female as complementary and inseparable.

Ware bases part of his critique on what he views as my inadequate reading of his 2014 monograph. He cites similarities between his work and that of Louise Lamphere (2000), faults my preference for engaging with Lamphere's work instead of his, and laments that he himself did not cite Lamphere's model, which was published 15 years prior to his. It is worth considering why this particular piece of Lamphere's scholarship, published in a volume on gender (Crown 2000), escaped Ware's notice.

Carrie C. Heitman — Department of Anthropology, University of Nebraska-Lincoln, 833 Oldfather Hall, PO Box 880368, Lincoln, NE 68588-0368, USA (cheitman2@unl.edu) 
Ware also critiques aspects of my scholarship (Heitman 2015) published outside the pages of American Antiquity. Contrary to Ware's assertion, house society models are not blind to issues of descent. Levi-Strauss's original formulation makes this clear; he defines house societies as

a corporate body holding an estate made up of both material and immaterial wealth, which perpetuates itself through the transmission of its name, its goods and its titles down a real or imaginary line, considered legitimate as long as this continuity can express itself in the language of kinship or of affinity and, most often, of both [Lévi-Strauss 1982:174].

Subsequent re-theorizations (e.g., Carsten and Hugh-Jones 1995) and archaeological applications (e.g., Beck 2007; Gillespie 2000; Heitman 2011; Richards and Jones 2016) also make this quite clear.

Lastly, I note that recent DNA findings from Chaco Canyon (Kennett et al. 2017) do not, as Ware contends, explain "female symbolism" in Chacoan society, and his use of the word "symbolism" highlights the need, as Wylie (1997) argued 20 years ago, to advance feminist science. The DNA analysis demonstrates that females were not simply symbols in Chacoan society, but were the gender through which kin group inheritance passed. Homologous ethnographic evidence from modern Pueblos would suggest that women may have been land owners and curators of ritual paraphernalia stored within houses (Heitman 2011:84-138). Based on their evidence for hereditary leadership through an elite matriline, Kennett and colleagues (2017:5) describe "matrilineal leaders as key protagonists in social history." This seems like a productive avenue for future anthropological inquiry.

\section{References Cited}

Beck, Robin A., Jr.

2007 The Durable House: Material, Metaphor, and Structure. In The Durable House: House Society Models in Archaeology, edited by Robin A. Beck Jr., pp. 3-24.
Center for Archaeological Investigations, Occasional Paper No. 35. Southern Illinois University, Carbondale. Carsten, Janet, and Stephen Hugh-Jones

1995 Introduction. In About the House: Lévi-Strauss and Beyond, edited by Janet Carsten and Stephen HughJones, pp. 1-46. Cambridge University Press, Cambridge.

Crown, Patricia L. (editor)

2000 Women and Men in the Prehispanic Southwest: Labor, Power, and Prestige. School of American Research Press, Santa Fe, New Mexico.

Gillespie, Susan

2000 Beyond Kinship: An Introduction. In Beyond Kinship: Social and Material Reproduction in House Societies, edited by Rosemary A. Joyce and Susan D. Gillespie, pp. 1-21. University of Pennsylvania Press, Philadelphia.

Heitman, Carrie C.

2011 Architectures of Inequality: Evaluating Houses, Kinship and Cosmology in Chaco Canyon, New Mexico, A.D. 800-1200. Ph.D. dissertation, Department of Anthropology, University of Virginia, Charlottesville.

2015 The House of Our Ancestors. In Chaco Revisited: New Research on the Prehistory of Chaco Canyon, New Mexico, edited by Carrie C. Heitman and Stephen Plog, pp. 215-248. Amerind Studies in Archaeology Series, University of Arizona Press, Tucson.

2016 "A Mother for All the People": Feminist Science and Chacoan Archaeology. American Antiquity 81:471489.

Kennett, Douglas J., Stephen Plog, Richard J. George, Brendan J. Culleton, Adam S. Watson, Pontus Skoglund, Nadin Rohland, Swapan Mallick, Kristin Stewardson, Logan Kistler, Steven A. LeBlanc, Peter M. Whiteley, David Reich, and George H. Perry

2017 Archaeogenomic Evidence Reveals Prehistoric Matrilineal Dynasty. Nature Communications 8:14115. DOI:10.1038/ncomms14115, accessed May 15, 2017.

Lamphere, Louise

2000 Gender Models in the Southwest: A Sociocultural Perspective. In Women and Men in the Prehispanic Southwest: Labor, Power, and Prestige, edited by Patricia L. Crown, p. 379-402. School of American Research Press, Santa Fe, New Mexico.

Levi-Strauss, Claude

1982 The Way of the Masks. Translated by Sylvia Modelski. University of Washington Press, Seattle.

Richards, Colin, and Richard Jones (editors)

2016 The Development of Neolithic House Societies in Orkney. Windgather Press, Oxford.

Ware, John A.

2014 A Pueblo Social History: Kinship, Sodality, and Community in the Northern Southwest. School for Advanced Research Press, Santa Fe, New Mexico.

Wylie, Alison

1997 The Engendering of Archaeology Refiguring Feminist Science Studies. Osiris 12:80-99.

Submitted April 7, 2017; Accepted April 8, 2017 